\title{
Relationship between Customer Service Innovation and Customer Satisfaction in the Banking Industry: A Case Study of Kenya Commercial Bank
}

\author{
Lucy Atieno Owano, Dr Ondiek Alala, DR Doouglas Musiega
}

\begin{abstract}
The aim of this research is to investigate the relationship that exists between service innovation and customer satisfaction in the banking sector. The study has analyzed the relationship between customer service innovation and customer satisfaction as the background of the problem by following up on the causes of customer satisfaction in the banking industry under the study and how it is affecting their reputation. The research further justifies the study and its significance as customer service innovation is one of the major changes brought about by competition and technological changes. In the research, limitations of conducting the study have been put on perspective and how they will be countered.

Banks in Kenya have continuously invested in service innovation practices to be able to satisfy their customers. The level of innovation varies from Bank to Bank and service to service. Customer service innovation has been explained under three outlooks including innovation in services as new or improved service products, innovation in service processes as new or improved ways in designing and producing services and finally innovation in service firms, organization and industries. Customer satisfaction is used as a measure of how products and services supplied by a company meet or surpass customer expectation and it is seen as a key performance indicator within businesses.

This research has sought to determine the customer service innovative practices in the Banking Sector and to establish the relationship that exists between customer service innovation and customer satisfaction in the banking sector. Primary data will be collected using a semi structured questionnaire, designed to be completed by respondents who are customers and staff of Kenya commercial bank-Kencom branch. The data has been checked for completeness and analyzed using descriptive statistics.
\end{abstract}

\section{Introduction}

According to Metcalfe (2006), Service Innovation can be defined as a new or considerably changed service concept, client interaction channel, service delivery system or technological concept that individually, but most likely in combination, leads to one or more renewed service functions that are new to the firm and do change the service/good offered on the market and do require structurally new technological, human or organizational capabilities of the service organization.

Innovation is the application of better solutions that meet new requirements, unarticulated needs, or existing market needs. This is accomplished through more effective products, processes, services, technologies, or ideas that are readily available to markets, governments and society. The term innovation can be defined as something original and, as consequence, new that "breaks into" the market or society. One usually associates to new phenomena that are important in some way. A definition of the term, in line with these aspects, would be the following: "An innovation is something original, new, and important in whatever field that breaks in to or obtains a foothold in a market or society" (Lundvall, 2007).

The process of translating an idea or invention into a good or service that creates value or for which customers will pay. To be called an innovation, an idea must be replicable at an economical cost and must satisfy a specific need. Innovation involves deliberate application of information, imagination and initiative in deriving greater or different values from resources, and includes all processes by which new ideas are generated and converted into useful products (Wamae, 2010). In business, innovation often results when ideas are applied by the company in order to further satisfy the needs and expectations of the customers. In a social context, innovation helps create new methods for alliance creation, joint venturing, flexible working hours, and creation of buyers' purchasing power.

Innovations are divided into two broad categories: "Service innovation" is a broad term that has to do with making changes in the direction, organization and even the product line of an entity in order to anticipate demand and keep the company in the forefront of an industry (Metcalfe, 2006). Sometimes referred to as anticipatory thinking or anticipatory innovation, the idea is to accurately project upcoming trends within the marketplace and makes changes in the way the company does business in order to ride the wave of those trends to greater financial rewards. Considered a hallmark of true entrepreneurship, service innovation will often 
involve a combination of changes that affect various levels of the operation, depending on what is required to produce the desired result.

According to Furman (2002), states that service innovation focuses on making changes to a product line in order to attract more attention from consumers. This may involve enhancements to existing products that are likely to increase demand from a wider range of customers, or the introduction of new products to an existing line that allows the company to move into consumer niche markets that were previously unexplored. Both approaches tend to focus on adding value to consumers that the competition cannot supply.

The process of service innovation can also focus more on making a company more efficient in terms of its operational structure. Here, the idea may be to change the internal structure so that waste is eliminated, production is increased, and customer orders can be processed in less time (Kuusisto \& Riepula, 2009). The end result in this scenario is a company with lower operating costs and a reputation for delivering the goods quickly and reliably. As a result, consumers are more likely to buy products over and over, which in turn increases revenue generation for the business. A third example of service innovation relates to providing customer support before, during, and after a sale. This is often accomplished by creating mechanisms that allow easy communication between customers and those in the bank that can assist with questions or concerns. To this end, many banks will provide multiple means of communication that include the use of traditional customer service telephone numbers, augmented with the possibility of email communications and even online support by way of a customer forum or a real-time chat feature. The idea is to be accessible to the customer and provide clear and concise support that is delivered in a time frame the customer perceives as being beneficial (Junarsin, 2010).

The general idea of service innovation is to take something that is good and make it better. In order to accomplish this, careful scrutiny of how things are done today in the banking industry, and why those procedures are in place, is vital. From there, evaluating the relevancy of those processes and procedures in light of today's marketplace can commence, hopefully identifying at least a few ways the banking industry can change and present a greater value to consumers. When managed responsibly, service innovation enhances the general operation of the company and increases customer loyalty demand for the products offered in the marketplace (Schumpeter, 2006).

According to Furman (2002) customer satisfaction is customer's reaction to the state of service offered, and customer's judgment of service delivery level. Customer satisfaction is very important in today's banking industry, the ability of a service provider to create high degree of satisfaction is crucial for product differentiation and developing strong relationship with customers. Customer satisfaction is an ambiguous and abstract concept. Actual manifestation of the state of satisfaction will differ from one person to another, from one product or service to another. The state of satisfaction depends on a number of factors which consolidate as psychological, economic and physical factors. These factors are a good guide on the direction to take with regard to service innovation in the sector.

According to Berry (2003) in the context of the service sector, relationship marketing has been defined as attracting, maintaining and enhancing customer satisfaction. To the researcher, attracting customers is considered to be an intermediary step in the relationship building process with the ultimate objective of increasing loyalty of profitable customers. While for the academicians, relationship marketing is a paradigm shift in marketing philosophy emphasizing the importance of long term relationship and retaining existing customers over getting new customers.

Innovation derives the industry to grow, prosper and transform in sync with the changes in the environment, both internal and external. Banking is no exception to this, in fact, this sector has witnessed radical transformation of late, based on many innovations in products, processes, services, systems, business models, technology governance and regulation. A liberalized and globalized financial infrastructure had provided an additional impetus to this gigantic effort. The pervasive influence of information technology has revolutionaries banking. Transaction costs have crumbled and handling of astronomical brick and mortar structure has been rapidly yielding ground to click and order electronic banking with a plethora of new products. Banking has become boundary less and virtual with a 24 hours model. Banks who strongly rely on the merits of relationship was banking' as a time tested way of targeting and servicing clients have readily embraced Customer Relationship Management (CRM), with sharp focus on customer centricity, facilitated by the availability of superior technology. CRM therefore, has become a new mantra in service management, which in both relationship based and information intensive (Lundvall, 2005).

Thanks to the regulatory changes and financial innovation, large banks have now become complex organizations engaged in wide range of activities. Banking is now a one-stop provider with a high degree of competition and competence. Banking has become a part of financial services. Risk Management is no longer a mere regulatory issue (Tassey, 2007). Basel-2 has accorded a primacy of place to this fascinating exercise by repositioning it as the core banking. We now see the evolution of many novel deferral products like credit risk management tool that enhances liquidity and market efficiency. 
The retail revolution with accent on retail loans in the form of housing loans and Consumer loans literally dominating the banking globally is yet another example of product and service innovation.

\subsection{Statement of the Problem}

Service innovation has proved to be very important in all the sectors of the economy of a country. It has thus been the subject of much discussion over the past decade since there has been a move from traditional banking to the modern banking which is currently in use. In today's volatile environment, banks will not survive in this changing environment unless they focused their attention to service innovation thus creating and maintaining a formidable relationship with their customers.

Existing literature proposes that there is a positive relationship between service innovation and customer satisfaction in the banking industry. Numerous studies have shown positive links between innovation and customer satisfaction. Over the past years the interest in service innovation has increased considerably with banking attention shifting gradually to technological innovation so as to gain competitive edge over other players (Kraemer et al, 2010).

Despite the existence of a large and growing body of literature on the banking industry in general, there is still some inadequacy surrounding the practice and how it influences performance particularly in the banking sector. Most research in this area has been conducted in the developed countries with little attention on the developing countries. It is with this in mind that this study sets out to assess of the relationship between service innovation and customer satisfaction in the banking industry in Kenya.

In Kenya, customers demand efficient, fast and convenient services. Customers want an organization that will offer them services that will meet their particular needs (personalized) and support their Business goals for instance; tourists want to travel without carrying cash for security reasons. They want to transfer funds among accounts and even want to download transaction records into their own computer at work or home.

Customers want a preferential treatment and full attention. All these are only achievable through effective and up to date service innovation. In line with rendering quality and acceptable services that most organizations worldwide are gearing toward and investing large sums of money in information and communication Technology, expectedly such services have been improved.

The study will therefore identify the challenges in customer satisfaction and service innovation in the banking industry and proffer solutions to the same because some have criticized it for inefficiencies and delays in the implementation; hence the need for this study to contribute to the body of knowledge to assess the relationship between service innovation and customer satisfaction in the banking industry. The study will also seek to evaluate the impact of customer satisfaction, whether information technology and staff training has an impact on service innovation in the banking industry.

\subsection{Objectives of the Study}

\subsubsection{General Objective}

The main objective of this study is the assessment of the relationship between service innovation and customer satisfaction in the banking industry, a case study of KCB Bank.

\subsubsection{Specific Objectives}

The specific objectives the study sets to establish were:

(i) To determine how the concept of service affect customer satisfaction at Kenya Commercial Bank

\subsection{Significance of the Study}

The findings of the study will contribute to professional extension of existing knowledge in service innovation by helping in understanding current challenges for implementing service innovation in the banking industry in Kenya.

The study will also provide information to assist those interested in the banking industry activities and operations, especially concerning service innovation. It will, therefore, provide insight into the challenges and potential benefits of continuous service innovation. It will benefit all banks and financial institutions in undertaking service innovation activities and procedures.

It will also assist in the formulation of policies, standards, guidance and procedures for service innovation. The findings and recommendation will assist the banking industry come up with necessary regulations and guidelines that would foster banking business and ensure innovation in services rendered.

\subsection{Scope of the Study}

The study was conducted on all Kenya Commercial Banks in Nairobi central business district. 


\subsubsection{Concept of Service}

The term service has been defined by different authors over time. Lundvall (2005), defined a service as a product of essentially intangible benefit, either in its own right or as a significant element of a tangible product which through some form of exchange satisfies an identified need. (Metcalfe, 2006) on the other hand defined a service as a performance, which cannot be seen, touched, tested or smelled, nor can it be possessed. People do not always perform consistently and thus variations from one service to another within the same organization. Organizations therefore attempt to reduce their inconsistencies through standardization and training. Nelson, (2003) also described services in taxonomy of 3 groups: supplier-dominated services, production- intensive services and science- based services. Supplier dominated services are those that are provided by the public services e.g. education and health care and some distributive services e.g. retail trade. Supplier dominated services concern the services dependent on physical networks or dependant on information networks e.g. banks and insurances.

Finally science-based services are those which have innovation directly related to progresses in applied sciences e.g. electronics and bio-engineering.

Services have very unique characteristics that are distinctive in comparison to products. Services cannot be stored and very few services face constant pattern of demand throughout time. Many show variation which could be on daily, weekly, seasonal or cyclical. All of which display unpredictable patterns of demand. The intangible characteristics that define services such as reliability, personal care, attentiveness of staff and their friendliness can only be verified once a service has been bought and consumed. Analysis of the various definitions of indicates that most authors agree that a service is a type of economic activity that is intangible, is not stored, does not result in ownership and is consumed at the point of sale.

\subsubsection{Service Quality}

Service quality describes a customer's expectations. A business with high service quality will meet customer needs whilst remaining economically competitive (Lundvall, 2007).

Customers' perception of service quality and their satisfaction are profoundly influenced by their service encounters, (Metcalfe, 2006). A service encounter can be defined as the period of time during which a customer directly inter-acts with a service (Shoemaker, 2010). This includes all features of service with which a consumer may have any kind of interaction, going from personal to physical facilitations, or even non-human interactions (Ogden \& Wilson, 2002).

Customer's perception of service quality depends upon the size and direction of the gap between the service the customer expects to receive and what he or she perceives to have been received. The magnitude of this gap (which can either, be positive or negative) is determined by four interrelated variables: (1) the difference between actual consumer expectations and management perceptions of those expectations; (2) between management perception of expectations and the translation of those perceptions into service quality specifications; (3) between service quality specifications and service delivery; and (4) between both service quality specifications and service delivery, and external communications to customers. These gaps can be a major hurdle in attempting to deliver a service which consumers would perceive as being of high quality (Papaioannou, et al., 2006).

The banking industry is dominated by look-alike products at similar prices, superior customer service may be the only available route to competitive advantage. Customer service is no longer a matter of choice as the future of any organization depends on it, (Patel, 2005). Quality customer service delivery begins with establishing clear, concise, observable and realistic service standards that are precise in meaning, short and to the point which can be seen or measured, practical and attainable (Perez \& Soete, 2006).

When customers assess the quality of a service provided in a branch, they use different criteria that are called attributes. Many of which are interesting but only a few are the most important, (Hall et al., 2006). Those determinant attributes are the ones that will define service quality from the consumer's perspective. A variety of factors, including resource constraints, management perceptions of consumer expectations and the firm's service quality specifications affect service quality from the consumer's viewpoint.

\subsubsection{Service Innovation Practices}

Service innovation is a new or significantly improved service concept that is taken into practice. It has been described as for example new customer interactions channel, a distribution system or a technological concept or a combination of them. A service innovation always includes replicable elements that can be identified and systematically reproduced in other cases or environments. The replicable element can be the service outcome or the service process as such or a part of them (Toivonen et al., 2007).

According to Hall et al., (2006) service innovation benefits both the service producer and customers and it improves its developer's competitive edge. Service innovation is a service product or service process that is based on some technology or systematic method. In services however, the innovation does not necessarily 
relate to the novelty of the technology itself but the innovation often lies in the non-technological areas. Service innovations can for instance be new solutions in the customer interface, new distribution methods, novel application of technology in the service process, new forms of operation with the supply chain or new ways to organize and manage services.

Hall et al., (2006) described service innovation practices under three outlooks including innovation in services as new or improved service products, innovation in service processes as new or improved ways in designing and producing services which may include innovation in service delivery systems and finally innovation in service firms organization and industries.

\subsubsection{Service innovations practices in the Banking industry}

Service innovations are currently a priority for managers of many commercial banking organizations and it is a driver of performance and a key of growth as organizations in this industry operate in an extremely competitive and dynamic environment. There are many forms of banking innovations in the banking sector which include relationship banking, automated teller machines, telephone banking, internet banking, branch networking, electronic funds transfer, real time gross settlement system.

Relationship Banking has been developed and embraced by commercial banks as the relationship between the clients and banks is largely a contractual one. When completing a form to open an account, the client is offering his money to the bank, while the bank is at liberty to accept or reject the offer as it sees fit. Once both parties accept the terms as discussed, a relationship is formed between the parties (Georghious et al., 2006, Georgantzas et al., 2003). Relationship banking involves banks investing in building relationships with borrowers (Auluck, 2002). Auluck (2002) defines relationship banking as the provision of financial services by a financial intermediary that invests in obtaining customer-specific information, often proprietary in nature; and evaluates the profitability of these investments through multiple interactions with the same customer over time and/or across products. Auluck (2002) states that three conditions are met when relationship banking is present which are: The intermediary gathers information beyond readily available public information; Information gathering takes place over time through multiple interactions with the borrower, often through the provision of multiple financial mservices; and the information remains confidential (proprietary).

Relationship banking can increase the banks earnings by maximizing the profitability of the total customer relationship over time, rather than by seeking to extract the most profit from any individual product or transaction (Dattakumar et al, 2003). Auluck (2002) states that relationship banking can facilitate a Paretoimproving exchange of information between the bank and the borrower. With relationship banking, a borrower might be inclined to reveal more information than in a transaction-oriented interaction and the lender might have stronger incentives to invest in producing information.

The automated teller machine was described by Auluck (2002) as a device that combines a computer terminal, record-keeping system and cash vault in one unit, permitting customers to enter the bank's book keeping system with a plastic card containing a

Personal Identification Number (PIN). Once access is gained, it offers several retail banking services to customers. ATMs are mostly located outside of banks, and are also found at airports, malls, and places far away from the home bank of customers. They were introduced first to function as cash dispensing machines. However, due to advancements in technological innovations, ATMs are able to provide a wide range of services, such as making deposits, funds transfer between two or accounts and bill payments. Banks tend to utilize this electronic banking device, as all others for competitive advantage.

The combined services of both the Automated and human tellers imply more productivity for the bank during banking hours. ATMs also enhance customer satisfaction as they save customers time in service delivery as alternative to queuing in bank halls, enabling them to invest such time saved into other productive activities. ATMs are also a cost-efficient way of yielding higher productivity as they achieve higher productivity per period of time than human tellers (Auluck, 2002) Furthermore, as the ATMs continue when human tellers stop, there is continual productivity for the banks even after banking hours.

Telephone Banking is a service innovation that is considered as a form of remote or virtual banking. This is essentially the delivery of branch financial services via telecommunication devices where the bank customers can perform retail banking transactions by dialing a touch-tone telephone or mobile communication unit, which is connected to an automated system of the bank by utilizing Automated Voice Response (AVR) technology" (Byerlee et al., 2002). According to Lall (2001), telebanking has numerous benefits for both customers and banks. As far as the customers are concerned, it provides increased convenience, expanded access and significant time saving. On the other hand, from the banks' perspective, the costs of delivering telephone-based services are substantially lower than those of branch based services. It has almost all the impact on productivity of ATMs, except that it lacks the productivity generated from cash dispensing by the ATMs. This service innovation has enhanced customer satisfaction as it offers retail banking services to customers at 
their offices/homes as an alternative to going to the bank branch/ATM. This saves customers time, and gives more convenience for higher productivity.

The idea of Internet banking is to give customers access to their bank accounts via a web site and to enable them to enact certain transactions on their account, given compliance with stringent security checks (Lall, 2001). Internet Banking has also been described as the provision of traditional banking services over the internet. Internet banking by its nature offers more convenience and flexibility to customers coupled with a virtually absolute control over their banking (Mulaa, 2004). Internet banking has in time proven to be the one of the most cost efficient technological means of yielding higher productivity.

Furthermore, it eliminates the barriers of distance/time and provides continual productivity for the bank to unimaginable distant customers (Mulaa, 2004). Branch Networking is the computerization and interconnecting of geographically scattered stand-alone bank branches, into one unified system in the form of a Wide Area Network (WAN) or Enterprise Network (EN) for the creation and sharing of consolidated customer information/records (Agwu et al., 2008). It offers quicker rate of inter-branch transactions as the consequence of distance and time are eliminated. Branch networking as a service innovation enhances more productivity per time period. With the several networked branches serving the customer populace as one system, there is simulated division of labor among bank branches with its associated positive impact on productivity among the branches. Furthermore, branch networking enhances customer satisfaction as it curtails customer travel distance to bank branches more time to engage in other productive activities.

The Electronic Funds Transfer at the Point of Sale is an additional service innovation that is widely used by commercial banks. It is an on-line system that allows customers to transfer funds instantaneously from their bank accounts to merchant accounts when making purchases (at purchase points). A POS uses a debit card to activate an Electronic Fund Transfer Process (Byerlee et al., 2002). Increased banking productivity results from the use of EFTPoS to service customers shopping payment requirements instead of clerical duties in handling cheques and cash withdrawals for shopping. Furthermore, the system continues after banking hours, hence continual productivity for the bank even after banking hours. It also saves customers time and energy in getting to bank branches or ATMs for cash withdrawals which can be harnessed into other productive activities. Real Time Gross Settlement (RTGS) system is one of the newest service innovations in the banking industry and the fastest money transferring mechanism between the banks. In RTGS, the transactions are processed and settled in "Real time" and on "Gross" bases.

Once the transaction is settled, it is irreversible. "Real time" means as and when the transaction is processed while "Gross" means the transaction is settled individually without being clubbed with other transactions. The RTGS system has led to increased banking productivity as it has led to reduction of settlement risk due to settlement lag, reduced credit risk and speed up processes of high value payments (Auluck, 2002).

\subsubsection{Customer Satisfaction}

Customer satisfaction has been the subject of considerable research, and has been defined and measured in many ways (Byerlee et al., 2002). It is either that customers are satisfied with the services they receive or dissatisfied. If customers gets what they want they are satisfied, if not they are dissatisfied. Customer satisfaction is the degree of fit between customers' expectations of service quality and the service as perceived by the customer. It is the customer's fulfillment response to a customer experience, or some part thereof (Byerlee et al., 2002). Customer satisfaction is a pleasant fulfillment response while dissatisfaction is an unpleasant fulfillment response. The experience or some part there of component of the definition suggests that the satisfaction evaluation can be directed at any or all elements of the customer's experience. This can include product, service, process and any other components of the customer experience (Hall, 2005).

\subsubsection{Service Innovation practices and Customer Satisfaction}

Patel (2005) described service innovation as something which provides benefit to its developer and may also be profitable for other companies that will follow through imitation. Tassey (2007) indicates different kind of innovations based on their model, "Radical innovation". Through this system, organizations can achieve either recombinative innovation or formalization innovation. Re-combinative or architectural innovation takes place when a new service is developed either by combining characteristics of two or more existing services (bundling) or by splitting up an existing service (unbundling). Formalization innovation occurs by clarifying the relationship between technical characteristics and final characteristics.

The most common way of quantifying satisfaction is to compare the customer's perception of an experience, or some part of it, with their expectations. This is known as the expectations disconfirmation model of customer satisfaction. Using this model, customer satisfaction can be categorized by the level of customer expectation. This model suggests that if customers perceive their expectations to be met, they are satisfied. If their expectations are underperformed, this is negative disconfirmation and they will be dissatisfied. Through service innovation, companies can create highly satisfied customers who are loyal to the organization. This is 
beneficial to the organization as the customers spread positive word-of-mouth, in essence, becoming a walking, and talking advertisement for the firm. If there are many delighted customers spreading positive word-of-mouth communication, this then lowers the cost of promotion to attract new customers (Byerlee et al., 2002).

Shoemaker (2010) also indicates that highly satisfied customers are more forgiving; therefore the firm can occasionally slip up and not and lose customers. Having highly satisfied customers then, is like having an insurance policy against something going wrong in the service encounter. Essentially, customer satisfaction can be seen as a means of achieving business goals as well as being a source of sustainable competitive advantage.

\section{Conceptual Framework}

The following shows the diagrammatical framework of the independent variables and the dependent variable of the study.

\section{Conceptual Framework}

\section{Independent Variables}

\section{Dependent Variable}

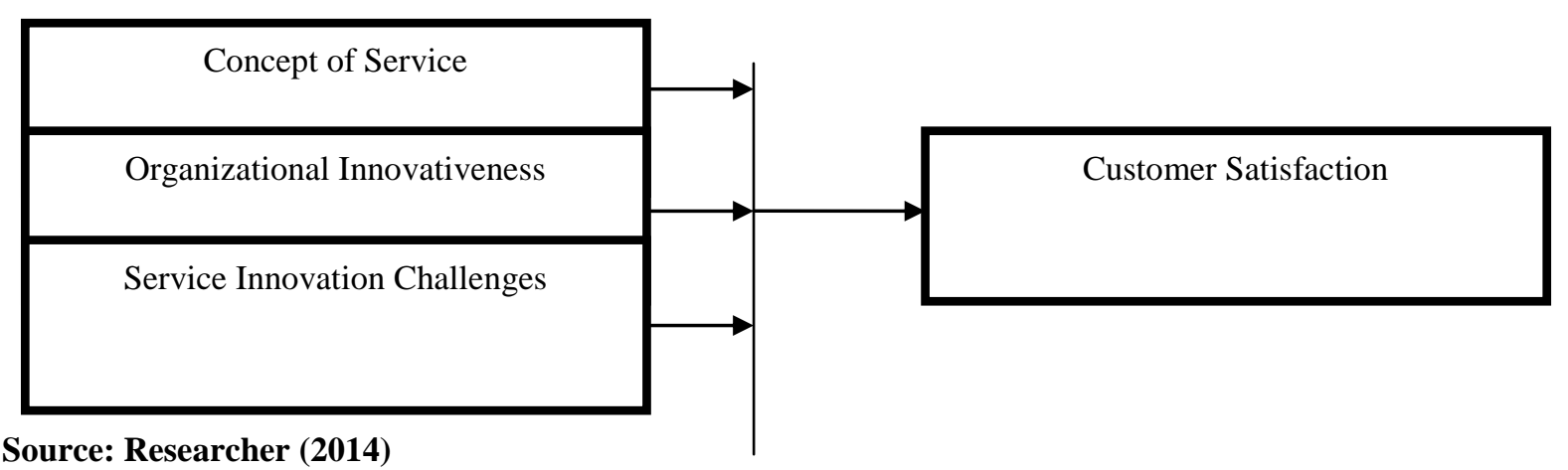

Source: Researcher (2014)

\section{Research Design}

The study used descriptive survey design which according to Jackson (2009) is used to describe a set of observations or the data collected. It is appropriate where the study seeks to describe the characteristics of certain groups, estimate the proportion of people who have certain characteristics and make predictions.

Research design refers to the method used to carry out a research. According to Uma Sekaran (2006) a descriptive research seeks to understand characteristics of individuals or organizations by offering a profile to describe relevant aspects of the phenomena of interest. This research will adopt a descriptive research design since the main objective is to establish the relationship that exists between service innovation and customer satisfaction in the banking sector. The main focus of this study was quantitative, that is to find the relationship that exists between service innovation and customer satisfaction in the banking sector. Through descriptive survey, the researcher was able to answer questions relating to the what, why and how of the phenomenon of service innovation and is impact to customer satisfaction.

Descriptive survey research design is used in preliminary and exploratory studies to allow researchers to gather information and summarize present and interpret data for the purpose of clarification (Ordhos, 2003). According to Patricia and Nandhini (2013), descriptive research is used to describe characteristics of a population or phenomenon being studied. It does not answer questions about how/when/why the characteristics occurred. Rather it addresses the "what" question (What are the characteristics of the population or situation being studied?). It is used to determine and report the way things are and it helps in establishing the current status of the population under study. The design chosen for the study due to its ability to ensure maximization of reliability of data collected.

\section{Population of Study}

Target respondents for the study were employees and customers in the Kenya Commercial Bank, Kencom Branch. A population of 320 respondents were selected randomly to avoid favoritism so as to represent all workers and customers in the banking industry.

As shown in table 4.7 above, technology is positively related to service innovation in banks. This is shown by the positive sign of the coefficient. The coefficient is statistically significant as indicated by a t-ratio of 2.438. This concurs with a study done by Owens, (2006) technology systems have associated data and network security risks which make them susceptible for conducting financial transactions. Technology risks regarding information and data security based on service innovation in the banking industry have been reported consequently creating uncertainty to the clients. 


\section{Findings and conclusions}

Service quality is positively related to service innovation in banks and has the most statistically significant coefficient as indicated by a t-ratio of 2.439. This implies that a one unit change in service quality will change the level of service innovation by 1.593 units. This coincides with Mckay, (2010) study that as businessmen around the world seek to encourage the provision of financial services to the unbanked and underbanked poor, they implement regulatory frameworks that enable the spread of low-cost branchless banking while at the same time they maintain the level of quality.

There is a positive relationship between communication and service innovation in banks. Service innovation also has a statistically significant coefficient as indicated by a t-ratio of 2.210. A one unit change in the communication will change the service innovation by 1.367 units. This concurs with World Bank, (2010) report that communication with clients is very vital in the banking industry since clients are the recipients of the services offered ad thus if not consulted innovation would be uncalled for if they don't fit the recipients demand. The study targeted a sample size of 160 respondents from which 130 filled in and returned their questionnaires making a response rate of $81 \%$. This response rate was satisfactory to make conclusions for the study. From the findings the study found that majority of the respondents as shown by $90 \%$ indicated that they were males whereas $10 \%$ of the respondents indicated that they were females. The study found that most of the respondents as shown by $51.5 \%$ indicated that they were aged $31-40$ years, $26.9 \%$ of the respondents indicated 21 to 30 years, whereas $21.5 \%$ of the respondents indicated $41-50$ years

\section{Conclusions of the Study}

The study concludes that both genders were represented in the study and therefore the finding of the study would not suffer from gender biasness and all ages were represented an indication that respondents were well distributed in terms of their age. In addition the study concludes that most of the employees of the bank had a degree, all the levels of the organization were represented in the study and that the majority of the respondents had served in their organization for more than 5 years and so give credible information.

\section{Service Innovation}

The study also concludes that in new product and service introductions, the bank is often first-to market, new products and services are often perceived as very novel by customers, in comparison with the competitors, the bank has introduced more innovative products and services during the past five years, in comparison with its competitors, the bank is faster in bringing new products or services into the market, in comparison with its competitors, the bank has a lower success rate in new products and services launch, the bank's most recent new product introduction required a new form of advertising and promotion, different from that used for its existing products, in new product and service introductions, the bank is often at the cutting edge of technology, in comparison with its competitors, it is are not late in adoption of technological innovations, the banks R \& D or product development resources are not adequate to handle the development needs of new products and services, the bank is constantly improving its business processes, the bank changes service methods at a great speed in comparison with its competitors, its future investments in new methods of banking are significant compared to its annual turnover, during the past five years, the bank has developed many new management approaches, the employees get a lot of support from managers if they want to try new ways of doing things, key executives of the firm are willing to take risks to seize and explore 'chancy' growth opportunities, management actively responds to the adoption of "new ways of doing things" by main competitors, in the bank, the staff tolerate individuals who do things in a different way, we are willing to try new ways of doing things and seek unusual, novel solutions and when we cannot solve a problem using conventional methods and the bank improvises on new methods.

\section{Customer Satisfaction}

The study also concludes that the bank shows sincere interest in solving customers' problems, it performs the service right the first time and the behaviour of employees in banks instills confidence in customers, the employees understand the specific needs of their customers, employees are neat in appearance, employees provide their services at the time they promise to do so, employees are consistently courteous with customers, employees always try to establish a good relationship with customers, employees show hospitality to customers and employees are highly efficient.

The study also concludes that the bank has account managers who take care of corporate customers, provides visiting services to corporate customers, provides a good channel of communication for customers, promotes their corporate culture to customers, take the initiative to serve customers and provides customertailored services to customers. 
The study also concludes that the bank uses the latest technology in their services, the online services are reliable and secure, it supplies helpful information in its online services and banks supply up-to-date information in their online services.

The study also concludes that the banks customers were extremely satisfied with the fast account/balance information, confidentiality of information transfer, ease of handling your banking needs, overdraft facility, cost of services, interest results, reporting of results, ease and frequency of contact, attentiveness to your banking needs. in addition they were extremely satisfied with the satisfaction with banks service level, visually appealing physical facilities, neat-appearing employees, visually appealing materials associated with the service (such as pamphlets and statements), employees telling customers exactly what services will be performed, employees never being too busy to respond to customers' requests while they were very satisfied by keeping a promise to do something by a certain time, showing sincere interest in solving a customer problem, performing the service correct at the first time, providing the service at the time the service was promised, insisting on error-free records, employees giving prompt service to customers, employees always being willing to help customers, employees never being too busy to respond to customers' requests, the behaviour of employees instilling confidence in their customers, customers feeling safe in their transactions, employees being consistently courteous with their customers, employees having the knowledge to answer customers' questions, giving customer's individual attention, operating hours convenient to all their customers, employees giving customers personal attention, having the customer's best interest at heart, the employees understanding the specific needs of their customers.

\section{Recommendations}

Given intense competition within the corporate banking market, banks are increasingly aware of the importance of service quality in contributing to the development of good bank-corporate relationships. Improving such relationships should increase bank profitability and accrue other benefits such as: commitment, co-operation and exchange of information.

First, banks should provide reliable services in order to achieve high levels of customer satisfaction, an antecedent of sustainable competitive advantage. Second, bank management should regularly provide adequate training for bank staff. The training could be costly and might not result in short-term profitability; however, lack of training will lead to problems in the long run. Bank management should also recruit staff with social skills that assist the development of long-standing relationships with customers. Third, bank management should emphasize the communication dimension and its related items. Any adjustments of short-term or long-term strategy concerning bank-corporate relations need to be communicated accurately and in timely fashion to bank employees and corporate customers. Fourth, bank management should pay attention to the influence of the latest technology on service quality.

This study has some limitations which are suggestive for future research. First, the data was collected from respondents of one commercial bank branch in Nairobi. Hence, the findings of this study may not be generalizable to other contexts. A direction for future research would be to replicate this study in other banks and with a larger sample size to assess the relationship between service innovation and customer satisfaction in the banking industry.

\section{Areas for Further Research}

Following the discussions highlighted in the study, the research suggests that further investigation should be conducted on what parameters and how banks determine the service innovation practices to engage in. In addition, further study should be conducted on the influence of service innovations on non commercial financial institutions in Kenya.

\section{References}

[1]. Aday Lu Ann \& Cornelius L.J (2006) Designing and conducting health surveys- A comprehensive Guide, $3^{\text {rd }}$ edition. Jossey-Bass

[2]. Agwu, A. E., Dimelu, M. U. \& Madukwe, M. C. (2008). Innovation System Approach To Agricultural Development: Policy Implications For Agricultural Extension Delivery In Nigeria, African Journal of Biotechnology Vol. 7 (11).

[3]. Auluck, R. (2002). Benchmarking: A Tool for Facilitating Organizational Learning? Public Administration and Development.

[4]. Byerlee, D. \& Alex, G. (2002). The Evolution of Public Research Systems In Developing Countries: Facing New Challenges. In: Byerlee, Agricultural Research Policy in an Era of Privatization. CABI Publishing, Wallingford.

[5]. Central Bank of Kenya, (2011). Banks Annual Supervision report 2011.retrieved from www.centralbank. go.ke

[6]. Chruchill, L. (2002). Research Design, Qualitative, Quantitative and Mixed Methods Approaches New York: Free Press.

[7]. Dattakumar R. \& R. Jagadeesh, (2003). "A Review of Literature on Benchmarking", Benchmarking: An International Journal, Vol. 10 (3).

[8]. Edquist, L (2004). Systems of Innovation: Technologies and Institutions. Edquist. L (Eds.), Systems of Innovation: Technologies, Institutions and Organizations, Pinter/Cassell, London Freeman.

[9]. Eriksson, E.A \& Weber, K.M. (2008). Adaptive Foresight: Navigating the complex landscape of policy strategies. Technological Forecasting and Social Change. Vol. 75(4),

[10]. Furman, J., M.E. Porter \& S. Stern (2002). The Determinants of National Innovative Capacity, Research Policy, 31 (1). 
[11]. Gavigan, J., Scapolo, F. \& Keenan, M (2001). A Practical Guide to Regional Foresight, McGraw-Hill, New York, NY.

[12]. Georgantzas, N. C. \& Acar, W. (2003). Scenario-driven Planning: Learning to Manage Strategic Uncertainty, Westport, CT: Quorum.

[13]. Georghiou, L., \& Keenan, M., (2006). Evaluation of National Foresight Activities: Assessing Rationale, Process and Impact, Technological Forecasting and Social Change, 73 (3).

[14]. Grupp H., Mogee M.E. (2004). Indicators for national science and technology policy: how robust are composite indicators? Research Policy, 33 (9).

[15]. Hall, A. (2005). Capacity Development for Agricultural Biotechnology in Developing Countries: An Innovation Systems View of What It Is and How to Develop It, Journal of International Development, 17.

[16]. Hall, A., Janssen, W., Pehu, E. \& Rajalahti, R., (2006). Enhancing Agricultural Innovation: How to Go Beyond Strengthening Research Systems. World Development.

[17]. Jackson, S. L. (2009). Research Methods and Statistics: A Critical Thinking Approach (3 ${ }^{\text {rd }}$ Edition). Belmont, CA, Thomson/Wadsworth

[18]. Jackson, S.L. (2009). Research Methods and Statistics: A Critical Thinking Approach 3rd edition. Belmont, CA: Wadsworth.

[19]. Kaganzi, B (2003) Participation in market research to identify income-generating opportunities. CIAT Africa Highlight.

[20]. Kemmis, S. \& McTaggart, R. (2001). The Action Research Planner ( $4^{\text {th }}$ ed.). Geelong, Victoria: Deakin University Press.

[21]. Kraemer-Mbula, E \& Wamae, W. (2010). Innovation and the Development Agenda. OECD Publishing, Paris.

[22]. Kraemer-Mbula, E. (2009). Building Technological Capability In Developing Countries: A Study of ICT Firms In South Africa, Unpublished PhD Thesis, Department of International Development: University of Oxford, UK.

[23]. Lall, S. (2001). Competitiveness Indices and Developing Countries: An Economic Evaluation of the Global Competitiveness Report, World Development.

[24]. Lundvall, B.A. (2005). National Systems of Innovation: Towards a Theory of Innovation and Interactive Learning, Pinter, London.

[25]. Lundvall, B.A. (2007). National Innovation Systems - Analytical Concept and Development Tools, Industry and Innovation, Journal of International Development 14 (1).

[26]. Metcalfe, J.S. (2005). Technology systems and technology policy in an evolutionary framework, Cambridge Journal of Economics, (19).

[27]. Metcalfe, J.S. (2006). Innovations, competition, and enterprise: foundations for Economic Evolution in Learning Economics“ in Hage, J. and M. Meeus, (eds.), Innovation, Science and Institutional change, New York: Oxford University Press.

[28]. Mugenda and Mugenda (2003) Quantitative and Qualitative Approaches. African Centre for Technology Studies. Nairobi.

[29]. Mulaa, N (2004). Competitive strategies adopted by small scale business in Nairobi, Nairobi: McMillan Press.

[30]. Murage, S (2001). Competitive strategies adopted by members of the Kenya Independent Petroleum Dealers Association, Nairobi: McMillan Press.

[31]. Nelson, R.R. (ed.) (2003), National Innovation Systems: A Comparative Analysis, Oxford University Press, Oxford.

[32]. Ogden, S.M. \& Wilson. P,(2002). Bridging the quality gaps: Implementing benchmarking to deliver Best Value, Journal of International Development 305(4).

[33]. Orodho, A. (2003). Essentials of Education And Social Science Research Methods. Nairobi: Masola publishers.

[34]. Papaioannou, T., Rush, H. \& Bessant, J. (2006). Benchmarking as a policy-making tool: from the private to the public sector. Science and Public Policy 33 (2).

[35]. Patel, P. (2005), Localised Production of Technology for Global Markets, Cambridge Journal of Economics, 19(1).

[36]. Patricia M. Shields \& Nandhini Rangarajan, (2013) A Playbook for Research Methods: Integrating Conceptual Frameworks and Project Management. Stillwater, OK: New Forums Press. Note - Shields \& Rangarajan devote a chapter to descriptive research (4). pp. $109-158$

[37]. Perez, C. \& L. Soete (2006), Catching-up in Technology: Entry Barriers and Windows of Opportunity, in G. Dosi, Technical Change and Economic Theory, Pinter Publishers, London.

[38]. Rosenberg, N. (2004), Critical issues in science policy research. In Nathan Rosenberg (ed.), Exploring the black box: Technology, economics, and history, Cambridge: UP.

[39]. Schumpeter, J.A. (2006), The Creative Response in Economic History, Journal of Economic History 7(2).

[40]. Schumpeter, J.A. (2002), The Creative Response in Economic History, Journal of Economic History, 50(2).

[41]. Shoemaker, J.H., (2010). Scenario planning: a tool for strategic thinking. Sloan Manage, 36 (2).

[42]. Tassey, G. (2007), The Economics of R\&D Policy, Praeger Publishers, Greenwood Publishing Group, United Kingdom.

[43]. Van der Heijden, K. (2006) Scenarios: The Art of Strategic Conversation, New York: John Wiley 